\title{
POPULIZM RUCHU PALIKOTA
}

\author{
Martyna Wasiuta*
}

\author{
POPULISM OF RUCH PALIKOTA
}

\begin{abstract}
This article deals with the Ruch Palikota political party, which has gained enough support in 2011 elections in Poland to be represented in Polish chamber of deputies - Sejm. One of the main opinions in media and within politicians is that Ruch Palikota (RP) is a populist party. This article attempts to examine the argument that the RP is not a populist party. A basic conception of populism is a description made by Roman Tokarczyk and Maria Marczewska-Rytko.
\end{abstract}

\section{KEYWORDS -}

populism, Ruch Palikota, left-wing

\section{WSTĘP}

O wieloznaczności pojęcia populizm mówi Jerzy Szacki ${ }^{1}$, Maria Marczewska-Rytko przyznaje że jego definiowanie jest jednym z najtrudniejszych zadań dla naukowców zajmujących się tym zjawiskiem², a jeden $z$ badaczy używa nawet

* Uniwersytet Kardynała Stefana Wyszyńskiego w Warszawie, Instytut Politologii.

1 J. Szacki, Populizm a demokracja, [w:] Populizm na przełomie XX i XXI w. Panaceum czy pułapka dla współczesnych społeczeństw?, red. M. Marczewska-Rytko, Toruń 2006, s. 13.

2 M. Marczewska-Rytko, New Populizm - Ideological-Instytutional Dimension, [w:] Populizm na przełomie XX i XXI w., op.cit., s. 78. 
określenia polisemii w kontekście omawiania definicji populizmu ${ }^{3}$. Także Radosław Markowski uważa, że termin ten używany jest w wielu kontekstach i ma kilka znaczeń ${ }^{4}$. Również niniejsza praca najprawdopodobniej nie sprawi, że pojęcie będzie bardziej ostre, gdyż nie jest to jej celem. Problemem badawczym niniejszego artykułu będzie populizm - faktyczny lub rzekomy - partii Ruch Palikota. W okresie kampanii wyborczej w 2011 roku i poźniejszym było wiele okazji, aby usłyszeć opinie na temat tego ugrupowania określające je mianem populistycznego, o czym więcej w dalszej części pracy. Jednak czy rzeczywiście spełnia ono warunki partii populistycznej?

Zakres czasowy niniejszej pracy obejmuje głównie pierwsze miesiące po przeprowadzonych wyborach parlamentarnych w 2011 roku, a więc po 9 października, kiedy przedmiotowa partia polityczna nosiła jeszcze nazwę Ruch Palikota ${ }^{5}$, otrzymała 10,02\% poparcia i uzyskała tym samym 40 mandatów w Sejmie oraz trzecie miejsce pod tym względem wśród pozostałych partii politycznych. W tym również okresie niniejszy tekst powstawał. Wykorzystane zostały między innymi opracowania naukowe w zakresie teorii i praktyki populizmu, głównie polskie, a także źródła internetowe: serwisy informacyjne, medialne, rządowe, wyniki badań opinii społecznej.

Na wstępnie przyjmuję hipotezę, iż partia Ruch Palikota nie jest partią populistyczną, gdyż nie spełnia wszystkich założeń paradygmatu populizmu. Część warunków istotnie wskazuje na pewien poziom populizmu stosowanego przez to ugrupowanie. Prawdopodobnie to właśnie one stały się źródłem takich opinii i uogólnień wśród innych polityków oraz w mediach. Jednoznacznie jednak nie można określić partii Ruch Palikota mianem populistycznej. Z racji tego, że określenie populizmu jest nacechowane emocjonalnie negatywnie i ma pejoratywne znaczenie ${ }^{6}$, ważne wydaje się właściwe posługiwanie się nim przy ocenie partii politycznych. Tym bardziej konieczne wydaje się przywołanie w niniejszej

3 D. Filc, Inclusive and Exlusionary Populizm: Attempt to Define a Blurred Concept, [w:] Populizm na przełomie XX $i$ XXI w., op.cit.

4 R. Markowski, Populizm a demokracja: ujęcia, dylematy, kontrowersje, [w:] Populizm a demokracja, red. R. Markowski, Warszawa 2004, s. 11.

${ }^{5}$ W 2013 r. nazwa partii została zmieniona na Twój Ruch.

${ }^{6}$ Radosław Markowski zaznacza, że obecnie występuje trend neutralizacji tego pojęcia. Por. ibidem. Eugeniusz Ponczek używa nawet określenia „syndrom populizmu”, co w metaforycznym ujęciu oznacza chorobę infekującą część społeczeństwa; można więc uznać to za przejawem negatywnej oceny zjawiska populizmu. E. Ponczek, Syndrom populizmu: trwałość - zmienność - następstwa, [w:] Populizm na przełomie XX i XXI w., op.cit., s. 67. 
pracy definicji zjawiska populizmu i jego istotnych elementów, które posłużą weryfikacji tezy o populizmie Ruchu Palikota.

\section{DEFINICJA I ISTOTA POPULIZMU}

Na wstępie zostało powiedziane, że definiowanie populizmu spotyka się z pewnymi problemami. Rzeczywiście nie jest łatwe przytoczenie jednej definicji, która całościowo realizowałaby jego założenia. Jest ich wiele i trudno stwierdzić, którą można uznać za tę jedyną, właściwą. Decydując się na jedną, po analizie literatury odnajduje się kolejne, które zawierają jeszcze inne elementy, często będące efektem różnych podejść do zjawiska. Typowym podejściem do wyjaśniania zjawiska populizmu jest rozpatrywanie go w kategoriach: a) politycznych działań, dyskursu (typ społecznej i politycznej mobilizacji), b) ideologii Pierwsze podejście wskazuje na cel, jaki podmiot obiera na wstępnie swoich działań, którym jest zdobycie poparcia społecznego i wyborczego. Można więc określić populizm mianem narzędzia, i to znaczenie przyjmuję na potrzeby niniejszej pracy.

Dzięki funkcjonalnemu podejściu udaje się wyodrębnić pierwszy element definicji populizmu, jakim jest specyficzne działanie na rzecz zdobycia przychylności, czyli zdobycia poparcia wyborczego ${ }^{8}$. Owa specyfika należy do istoty populizmu, jego wyznaczników. Według Romana Tokarczyka ${ }^{9}$ za takie można uznać następujące cechy, określane przez autora konstytutywnymi, a więc tymi, bez których populizm nie mógłby istnieć ${ }^{10}$ :

- niezadowolenie ludu,

- autorytet charyzmatyczny,

- myśl populizmu,

- metody populizmu,

- miejsca i czasy,

7 E. Nalewajko, Populizm w demokracji, [w:] Populizm a demokracja, op.cit., s. 41. Ewa Nalewajko przychylna jest pierwszemu ujęciu.

8 M. Marczewska-Rytko mówi o populizmie jako taktyce. Por. M. Marczewska-Rytko, op.cit. Ewa Nalewajko mówi wprost o populizmie łagodnym, wyborczym i oportunistycznym stosowanym przez Sojusz Lewicy Demokratycznej i Prawo i Sprawiedliwość. Por. E. Nalewajko, op.cit., s. 58.

9 R. Tokarczyk, Cechy konstytutywne myśli populizmu, [w:] Populizm na przełomie XX i XXI w., op.cit., s. 19-32.

10 Ibidem, s. 19. 
- hegemonia ludu,

- wielość inspiracji.

Należy zwrócić uwagę na fakt, że wyliczone powyżej cechy populizmu są w rzeczywistości tylko częściowo cechami opisującymi to zjawisko (autorytet charyzmatyczny, myśl populizmu, metody populizmu, wielość inspiracji), a częściowo wskazują na warunki i środowisko jako czynniki dodatkowo sprzyjające posługiwaniu się populizmem jako narzędziem (niezadowolenie ludu, miejsca i czasy, hegemonia ludu). Ponadto niektóre z nich mogą brzmieć ogólnie lub nie wyczerpywać pojęcia populizmu, dlatego też zostaną wzbogacone o dorobek innych autorów.

Niezadowolenie ludu jest odpowiedzią na pytanie o przyczynę populizmu i jego trwanie. Zjawisko to obserwujemy wraz z pojawieniem się autorytetu charyzmatycznego, świeckiego bądź religijnego i utrzymuje się dopóki lud ma nadzieję na poprawę warunków życiowych, podkreślaną przez retorykę wspomnianego autorytetu. Okresy depresji gospodarczych, szczególnie dotkliwie odczuwane przez najniższe warstwy społeczne określane ludem, sprzyjają zazwyczaj pojawianiu się populizmu i popieraniu reprezentujących go polityków. W momencie poprawy warunków bytu poparcie to znika ${ }^{11}$. Eugeniusz Ponczek mówi, że populizm to „wyraz wielkiego niezadowolenia społecznego, poczucie upośledzenia oraz krzywdy jego zwolenników, dążenie do przeciwstawienia się owej krzywdzie, za którą stoją jacyś ciemiężcy" ${ }^{12}$. Niezadowolenie ludu stanowi jego społeczne podłoże, grunt dla populistycznego przekazu polityka. W takich warunkach jest łatwiej budować poczucie zagrożenia, a kreowanie wroga - winnego całej sytuacji - wydaje się nieodzowne.

Populistyczne masy mają być inicjatorem i motorem reform, co stanowi wyraz nieufności, wrogości wobec istniejących struktur władzy, małych grup bezpodstawnie pretendujących do poziomu elit politycznych. Jest to grunt dla ujawniania się różnych teorii konspiracyjnych mających wykazać, że elity władzy są formami tajnych spisków, zmowy, mafii skierowanych przeciwko ludowi ${ }^{13}$. Taki antyelitaryzm powoduje „czarno-biały” obraz zjawisk społecznych i ludzi, pozwalający „dzielić ich np. na porządnych i uczciwych oraz wrogów i osoby zdemoralizowane”. Aprobata spiskowej koncepcji świata ma wyjaśnić przyczyny

\footnotetext{
${ }^{11}$ R. Tokarczyk, op.cit., s. 20.

12 E. Ponczek, op.cit., s. 68.

13 R. Tokarczyk, op.cit., s. 21.
} 
wszelkich niedomagań i nieszczęść ${ }^{14}$. Oprócz elit politycznych i bogactwa sprawcami niezadowolenia są inne ugrupowania, obcy itp. Często są nimi ludzie należący do mniejszości etnicznych, religijnych, światopoglądowych ${ }^{15}$. Takie tworzenie wroga, którego trzeba zwalczyć, kozła ofiarnego, sprawia, że ujawnia się ksenofobia i tendencje do utożsamiania się z nacjonalizmem ${ }^{16}$. Pojęcie populizmu wiązane jest z pojęciami etnocentryzmu i ksenofobii. Etnocentryzm jest tu rozumiany jako światopogląd odnoszący się do dychotomicznego podziału na „nas” i „nich”, który konstytuuje podstawę życia społecznego i kryteria oceny otaczającego świata. Owe „my” tworzy wyidealizowaną grupę, a „oni” są spostrzegani jako zagrożenie i źródło zła. Takie nastawienie zwykle prowadzi do zapobiegawczej izolacji i konfliktu. Ksenofobia z kolei polega na kreowaniu i głoszeniu takiego obrazu wspólnoty (matecznika), w którym nie ma miejsca dla ,innych”, co wpływa na kulturowy etos, zwykle bardzo fałszywy, postrzegany jako destrukcyjny dla danej kultury ${ }^{17}$

Drugą z wyżej wymienionych cech konstytutywnych jest charyzmatyczny przywódca (autorytet charyzmatyczny). Wyróżnia się on cechami osobowości zwanej charyzmą, obietnicami poprawy losy pociąga za sobą niezadowolone tłumy ${ }^{18}$. Wyraża najdoskonalej wolę ludu, jest charyzmatycznym mesjaszem, obdarzonym talentem demagogicznego trybuna, mającego zdolność nawiązywania mistycznego kontaktu z ludem. Lider potrafi schlebiać masom, żerując na ich irracjonalnych uczuciach, rozbudza emocje, iluzje i roszczenia, mnożąc obietnice bez pokrycia. Ma on również wizerunek ojca narodu, często w jego interesie jest utrzymywanie sytuacji kryzysowej, która stanowi źródło jego pozycji ${ }^{19}$.

Trzecią z cech konstytutywnych jest myśl populizmu, którą możemy interpretować jako program populistyczny. Są to więc obietnice złożone przez charyzmatyczny autorytet niezadowolonemu ludowi. Są one zgodne z lokalnymi uwarunkowaniami, potrzebami ekonomicznymi, politycznymi, kulturalnymi ludu ${ }^{20}$, co można określić mianem kontekstowości populizmu. Gardzi on „teoriami wysublimowanego intelektualizmu, nie potrzebuje oryginalnych treści, zapożyczając je z innych ideologii i dostosowując do własnych potrzeb. Są one

\footnotetext{
E. Ponczek, op.cit. s. 69.

15 R. Tokarczyk, op.cit.

16 E. Ponczek, op.cit.

17 M. Marczewska-Rytko, op.cit., s. 79.

18 R. Tokarczyk, op.cit.

19 Ibidem, s. 22.

20 Ibidem, s. 23.
} 
upraszczane i rozpraszane poprzez demagogię ${ }^{21}$. Cechuje je więc „eklektyzm aksjologiczny oraz niekoherencja poglądów" - zwolennicy populizmu aprobują te treści, ponieważ nie są wnikliwi intelektualnie (mogą być jednocześnie za i przeciw jakiejś wartości ${ }^{22}$.

Czwartą z cech konstytutywnych populizmu jest jego metoda - demagogia przekonująca adresatów treści do aprobaty nieprawdy poprzez apel do zdrowego rozsądku i logiki ${ }^{23}$. Stosowanie demagogii ma umożliwić urzeczywistnienie roszczeń ${ }^{24}$.

Piątym elementem tworzącym populizm jest jego osadzenie w czasie i przestrzeni. Uwarunkowane są one okolicznościami obiektywnymi - niezadowolenie ludu wyrażane przez charyzmatycznego przywódcę decyduje o miejscu i czasie tworzenia się populizmu. Ponieważ jest on wyrazicielem nastrojów ludu, w niewielkim stopniu może decydować o autokreacji w innych okolicznościach ${ }^{25}$. Przywódca populistyczny nie ma więc wpływu na swój sukces, jest on wynikiem zewnętrznego zapotrzebowania wyborców na taką postać.

Szósta cechą konstytutywną populizmu jest hegemonia ludu. Słuszne jest uznanie jej za jedną $\mathrm{z}$ fundamentalnych, $\mathrm{z}$ racji samej etymologii słowa „populizm”, które jednoznacznie nawiązuje do ludu ${ }^{26}$. Założenia i praktyka tego nurtu sprowadza „lud” do trzech znaczeń: a) synonim narodu, b) ogół ludności, która utrzymuje się z własnej pracy (robotnicza - M.W.), c) ludność wiejska ${ }^{27}$. W przypadku partii Ruchu Palikota owa cecha ma szczególne znaczenie, stąd ważne jest dogłębne znacznie ludu dla populizmu. Dani Filc proponuje trzy sposoby rozumienia tego terminu: 1) to cały naród, bez uwzględniania różnic/ podziałów klasowych, 2) to plebs jako przeciwieństwo elit, 3) to organiczna, etno-kulturowa koncepcja ludu ${ }^{28}$. Cechą wspólną każdego z wyżej wymienionych ujęć populistycznego ludu jest to, iż stanowi on większość. Sam Tokarczyk mówi o zgodności z oczekiwaniami większości ${ }^{29}$, a według M. Marczewskiej-Rytko to

\footnotetext{
${ }^{21}$ R. Tokarczyk, op.cit., s. 23.

22 E. Ponczek, op.cit., s. 69.

23 R. Tokarczyk, op.cit., s. 25.

24 E. Ponczek, op.cit.

25 R. Tokarczyk, op.cit., s. 27-28.

${ }^{26}$ K. Wojtas, Populizm, http://www.omp.org.pl/stareomp/index5efd.html?module=subjects\&fun $\mathrm{c}=$ viewpage\&pageid=339, odczyt $\mathrm{z}$ dn. 16.12.2012.

27 Ibidem, s. 28.

28 D. Filc, op.cit., s. 36.

29 R. Tokarczyk, op.cit., s. 20.
} 
większość zbliża się do odkrycia prawdziwych społecznych wartości, ideałów i celów. Powoływanie się na instynkt mas, wolę społeczeństwa jest częste. Stąd rządy większości opierają się na racji większości. Mniejszości mogą być tylko złe. Dla populistycznej wizji demokracja zbliża się do celu, którym jest włączenie preferencji i woli większości do powszechnie obowiązującego społecznego i politycznego kanonu ${ }^{30}$.

Siódmą i ostatnią cechą konstytutywną populizmu jest wielość inspiracji, czyli jego związki z różnymi ideologiami, stanowiącymi dla niego pewne podłoże ideowe. Ideologia sama $\mathrm{w}$ sobie nie musi wiązać się $\mathrm{z}$ populizmem, jednak w zestawieniu z pozostałymi jego wyznacznikami decyduje o określaniu partii mianem populistycznej. Eklektyzm ideologiczny sprawia, że sam w sobie populizm nie istnieje. Czerpie on z liberalizmu, konserwatyzmu, socjalizmu, komunizmu, nacjonalizmu, faszyzmu, zapożyczając treści tych myśli odpowiednio do potrzeb $^{31}$. Populizm nie wytworzył własnej linii ideologicznej, ale opiera się na rozwiązaniach już istniejących, zapożyczonych $\mathrm{z}$ innych znanych dotąd ideologii.

Dodatkowo odnajdujemy jeszcze: wezwanie do przyjęcia tzw. trzeciej drogi, czyli nowego porządku, rozumianego jako kompromis pomiędzy kapitalizmem a komunizmem. Oznacza to, że możliwa jest kombinacja najlepszych rozwiązań myśli socjalistycznej i kapitalistycznej. M. Marczewska-Rytko wspomina też o kombinacji idei chrześcijańskich i narodowych w nowym populizmie ${ }^{32}$,jednak zaznaczyć należy, że są to cechy nowego populizmu, a więc nie zawsze charakteryzowały partie populistyczne w przeszłości. W kontekście Ruchu Palikota, postulującego antyklerykalne hasła ma to szczególne znaczenie.

Zgodnie z typologią zaproponowaną przez Pierre'a Andre Taguieffa ${ }^{33}$ zakres $^{\prime}$ populizmu zaprezentowany przez R. Tokarczuka można przyporządkować do populizmu protestu (populizmu społecznego), natomiast charakterystykę M. Marczewskiej-Rytko - do populizmu tożsamości (narodowościowego).

30 M. Marczewska-Rytko, op.cit., s. 78-79.

31 R. Tokarczyk, op.cit., s. 29.

32 M. Marczewska-Rytko, op.cit.

33 P.A. Tagiueff, Political Science Confronts Populizm: from a Conceptual Miraże to a Real Problem, „Telos” 1995, nr 103, s. 32, [za:] W. Stankiewicz, Przejawy populizmu w Polsce i na świecie, [w:] Populizm na przełomie XX $i$ XXI w., op.cit., s. 352. 


\section{RUCH PALIKOTA A POPULIZM}

Kolejną częścią niniejszego opracowania będzie analiza praktyki funkcjonowania partii Ruch Palikota w odniesieniu do poszczególnych wyznaczników populizmu. Część z nich będzie wskazywała na fakt, że partia ta jest populistyczna, część - będzie zaprzeczać przyporządkowaniu jej do populizmu.

Zmienność poglądów lidera Ruch Palikota wydaje się najcięższym zarzutem o populizm tej partii, ocierającym się o wspomnianą kontekstowość oraz związek z koncepcją ${ }^{34}$ populistycznych partii marketingowych. Janusz Palikot wspierał finansowo tygodnik katolicki „Ozon”, obecnie związany jest z pismem antyklerykalnym „Fakty i Mity”. Można to oczywiście interpretować jako zmianę poglądów i niewątpliwie tak jest (sam polityk twierdzi, że jego poglądy się nie zmieniły ${ }^{35}$ ), ale nie można zapominać również, że lider Ruchu Palikota, zanim zaangażował się w działalność polityczną, był przedsiębiorcą, a więc lokował kapitał w intratnych przedsięwzięciach, jakimi niegdyś było prawdopodobnie czasopismo „Ozon”, a obecnie są to „Fakty i Mity”. Tłumaczy to w pewien sposób zmianę postawy i poglądów politycznych Janusza Palikota, można ją interpretować jako działania zgodne z paradygmatem teorii racjonalnego wyboru. Choć obniżenie wiarygodności wskutek radykalnej zmiany spektrum politycznego jest dość konkretnym zarzutem, to próbę wpisania się w korzystny trend uznać można jako naturalne zjawisko. Budzi skojarzenia z koniunkturalizmem, konformizmem, kontekstowością i w efekcie populizmem, jednak nie powinno się zapominać, że populizm to znacznie bardziej skomplikowane zjawisko, którego nie powinno sprowadzać się do jednej cechy.

Janusza Palikota za populistę uważa jeden z polityków Sojuszu Lewicy Demokratycznej Ryszard Kalisz: „Każdy populista znajdzie większego populistę" ${ }^{36}$. Reprezentant lewicy pozaparlamentarnej z Krytyki Politycznej Michał Sutowski mówi z kolei o antybiurokratycznym populizmie przewodniczącego Ruchu Palikota Janusza Palikota ${ }^{37}$. Z kolei Aleksander Smolar stawia tezę o Ruchu

${ }^{34}$ K. Wojtas, op.cit.

35 Janusz Palikot o sobie: ja mesjasz lewicy, rozmowa z Januszem Palikotem, http://polska.new sweek.pl/janusz-palikot-o-sobie--ja--mesjasz-lewicy,82197,4,1.html, odczyt z dn. 13.03.2012.

36 A. Kondzińska, Palikot u Lisa: Moi posłowie będą gwiazdami tego Sejmu, http://wyborcza. pl/1,76842,10447851,Palikot_u_Lisa__Moi_poslowie_beda_gwiazdami_tego_Sejmu.html?a $\mathrm{s}=2 \&$ startsz $=\mathrm{x}$, odczyt $\mathrm{z}$ dn. 17.12.2011.

37 Dodaje też, że umiejętnie wykorzystał on niszę handlową i popyt na ruch lewicowy, a Ruch Palikota był produktem, który korzystnie udało mu się sprzedać. Wypowiedź wzbudza skojarzenia z partiami populistycznymi marketingowymi, o czym szerzej pisze: K. Wojtas, Partie populistyczne 
Palikota jako „przejawie inteligenckiego populizmu, dowodzie bezsiły, kiedyś w Polsce bardzo wpływowej formacji społecznej", a Kinga Dunin wypowiada się o programie RP: „może populizm, ale na pewno nie dla tych elit, które wciąż dominują w życiu intelektualnym w Polsce" ${ }^{38}$, pojawia się też określenie „nowoczesnego populizmu dla wykształciuchów", a sam Janusz Palikot mówi o sobie, że jest jak Lepper ${ }^{39}$. Kazimierz Kik używa pojęcia liberalnego populizmu ${ }^{40}$. Widzimy więc, że debata na temat populizmu Ruchu Palikota istnieje, ale brak w niej zdecydowania. Co prawda autorytety dostrzegają pewien populizm w działaniach tej partii, ale znaczący jest też fakt, że towarzyszą mu jeszcze inne określenia: antybiurokratyczny, inteligencki, liberalny czy „dla wykształciuchów”, co budzi wątpliwości, czy rzeczywiście mamy do czynienia z populizmem w naukowym znaczeniu. Wątpliwości budzi też autoidentyfikacja Janusza Palikota z przewodniczącym populistycznej Samoobrony. Zabieg ten, najprawdopodobniej retoryczny, nie miał na celu wskazania na cechę swojego ugrupowania, tym bardziej że inni jego członkowie nie zgadzają się z przypisaniem jej ugrupowaniu Ruch Palikota ${ }^{41}$. Stwierdzenie to mogło stanowić dla jego lidera formę prowokacji, dość charakterystyczną dla działań tegoż ugrupowania. Trudno uwierzyć w tezę, aby sam polityk utożsamiał się ze zjawiskiem populizmu, nawet jeśli nieprzewidywalność jego zachowań i wypowiedzi stanowi dość częstą praktykę funkcjonowania tej partii i jej przewodniczącego. Mogłaby ona podważać wiarygodność ugrupowania i wskazywać na deficyt racjonalności lidera, co byłoby zakwestionowaniem dotychczasowych celów Ruchu Palikota, włącznie z wygraniem wyborów parlamentarnych. Co w takim razie jest populistycznego w Ruchu Palikota?

Weryfikacja hipotezy zaprzeczającej jakoby partia nie była populistyczna, gdyż nie spełnia wszystkich założeń populizmu uznawanych za konstytutywne, a więc dla niego istotnych, wymaga konfrontacji tych cech z rzeczywistością wytworzoną przez partię Ruch Palikota. Będą to m.in. wystąpienia medialne

w Czechach i na Słowacji, Warszawa 2011; Palikot: lewicowiec jednonożny, rozmowa z Michałem Sutowskim, http://wyborcza.pl/1,76842,10453409,Palikot_lewicowiec_jednonozny.html, odczyt $\mathrm{z}$ dn. 17.12.2011.

38 Fenomen Palikota: liberalizm integralny czy populizm dla elit?, materiały konferencyjne, zapis mp3, www.batory.org.pl, odczyt z dn. 17.12.2011.

39 Janusz Palikot o sobie: ja mesjasz lewicy, op.cit.

40 Sensacyjny scenariusz: jeśli SLD upadnie..., http://wiadomosci.wp.pl/title,Sensacyjnyscenariusz-jesli-SLD-upadnie,wid,14120477, wiadomosc.html?ticaid=1e175, odczyt z dn. 13.03.2012.

41 Eksperyment intelektualno-programowy, rozmowa z Wandą Nowicką, „Gazeta Finansowa” 2012, nr 1 . 
przewodniczącego partii, przekazy znajdujące się na stronie internetowej ugrupowania, dokumenty partyjne (statut i program), inne przekazy medialne.

Zgodnie z kolejnością zaproponowaną przez Romana Tokarczyka jako pierwsze poddane analizie zostanie niezadowolenie ludu. Powstanie populizmu jest jego wynikiem. Sięgając do korzeni ugrupowania Ruch Palikota, warto zaznaczyć, że powstanie partii nie miało charakteru oddolnego, w rozumieniu Maurice'a Duvergera partii tworzonej zewnętrznie, czyli przez grupy społeczne ${ }^{42}$. Inicjatywę o założeniu partii podjął jej przewodniczący Janusz Palikot, który dotychczas był posłem Platformy Obywatelskiej i z listy tej partii startował w wyborach w 2005 i 2007 roku. Z członkostwa w macierzystym ugrupowaniu ${ }^{43}$ i w klubie poselskim PO zrezygnował 6 października 2010 roku, stając się posłem niezrzeszonym. W styczniu następnego roku mandat Janusza Palikota wygasł, po czym w czerwcu zarejestrowana została partia polityczna Ruch Palikota, której przewodniczącym został sam J. Palikot ${ }^{44}$. Widzimy więc, że partia została założona przez byłego posła, jednak nie z inicjatywy osób zupełnie niezwiązanych dotąd z polityką. Ponadto inicjatywa ta nie była reakcją jej założyciela na wzrastające i masowe niezadowolenie w społeczeństwie, stanowiące potencjalny grunt dla populistycznych postulatów, ale na brak realizacji programu lewicowego dotychczasowych partii politycznych związanych z tym nurtem. Sprzyjał temu też okres przedwyborczy. Zatem poparcie dla partii może być efektem pewnego niezadowolenia, jednak nie spełnia ono parametru masowości. Jednym z czynników, które skłoniły Janusza Palikota do utworzenia nowej partii politycznej, była również sytuacja społeczno-polityczna w Polsce po tzw. katastrofie smoleńskiej i śmierci prezydenta ${ }^{45}$. Polityk podkreślał zbyt duży wpływ Kościoła na sprawy publiczne w kraju, czego symbolem były wydarzenia rozgrywające się w Warszawie na Krakowskim Przedmieściu. Nowe ugrupowanie miało być wyrazem sprzeciwu wobec tego zjawiska i chęci wprowadzenia zmian, które mogłyby zapobiec podobnym w przyszłości. Nie można jednak mówić tu o powszechnym niezadowoleniu ludu ze złych warunków życiowych, gdyż sytuacja, która doprowadziła do zainicjowania Ruchu Palikota, miała wymiar pozamaterialny, był to spór między tzw. zwolennikami krzyża (środowiska

42 R. Herbut, Teoria i praktyka funkcjonowania partii politycznych, Wrocław 2002, s. 125.

43 Składam rezygnacje, http://palikot.blog.onet.pl/Skladam-rezygnacje,2,ID415472696,n, odczyt $\mathrm{z}$ dn. 19.12.2012.

44 Ruch Palikota zarejestrowany, http://palikot.blog.onet.pl/2,ID428234076,index.html, odczyt z dn. 19.12.2011.

45 Palikot o sobie: ja, mesjasz lewicy, op.cit. 
Radia Maryja, zwolennicy Prawa i Sprawiedliwości oraz zmarłego prezydenta Lecha Kaczyńskiego) a różnymi przeciwnikami obecności symboli religijnych w miejscu publicznym. Większość Polaków pozytywnie oceniła postawę Kościoła podczas okresu żałoby narodowej (90\%) oraz udział jego przedstawicieli w uroczystościach pogrzebowych (73\% uznało go za odpowiedni), negatywne oceny postaw i opinie o nadmiernym eksponowaniu uczestnictwa kleru należały do mniejszości (odpowiednio 4\% i 21\%) ${ }^{46}$. W przełomowym dla powstania Ruchu Palikota ${ }^{47}$ okresie odnotowano ponadto wzrost o 5 punktów procentowych pozytywnych opinii o działalności publicznej Kościoła (z 68\% do 73\%) oraz spadek odsetka opinii negatywnych również o 5 punktów (z 23\% do 18\%) ${ }^{48}$. Reasumując, niezadowolenie społeczne z pozycji Kościoła nie było na tyle powszechne, aby stanowić punkt zapalny masowego protestu, nie mówiąc już o wymiarze tego konfliktu, który nie dotyczył sytuacji bytowych społeczeństwa. Interesujący również wydaje się fakt, że w lipcu 2010 roku to poziom nieufności do Janusza Palikota jako polityka był najwyższy w okresie jego obserwacji (czyli od 2008 roku), wynosił bowiem $54 \%{ }^{49}$.

Uzyskane przez Ruch Palikota poparcie nie jest efektem ogólnospołecznego niezadowolenia, gdyż jest ono, po pierwsze, dość niskie, po drugie, profil elektoratu nie uwzględnia wyborców niezadowolonych, wskazujących na poczucie krzywdy będącej efektem kryzysu ekonomicznego. W wyborach do Sejmu w roku 2011 Ruch Palikota otrzymał 10,02\% głosów, co oznacza, że głosowało na to ugrupowanie 1439490 wyborców ${ }^{50}$, przy liczbie wyborców uprawnionych do głosowania 30762 931, frekwencji 48,92\%. Oznacza to, że na Ruch Palikota w rzeczywistości głosowało ok. 5\% wyborców. Nie jest to liczba wskazująca na masowe niezadowolenie społeczne. Także cechy elektoratu RP nie oznaczają takiego stanu. Warto też dodać, że według Urszuli Jakubowskiej ma on określone

46 Polska i Polacy po katastrofie pod Smoleńskiem, Komunikat z badań CBOS, BS/78/2010, Warszawa 2010.

47 Zanim powstał Ruch Palikota, założone zostało Stowarzyszenie Ruch na rzecz Poparcia Palikota, później pierwsza próba zorganizowania w partię - Ruch Poparcia Palikota. Zob. Ruch Poparcia zarejestrowany, http://palikot.blog.onet.pl/Ruch-Poparcia-zarejestrowany,2,ID416670044,n, odczyt $\mathrm{z}$ dn. 19.12.2012.

48 Oceny instytucji publicznych $w$ kwietniu, Komunikat z badań CBOS, BS/54/2010, Warszawa 2010, przeprowadzono w dniach 8-19 kwietnia 2010 roku.

49 Wyborcy Ruchu Palikota, Komunikat z badań CBOS, BS/149/2011, Warszawa 2011.

50 Liczba głosów ważnych, http://wybory2011.pkw.gov.pl/wyn/pl/000000.html\#tabs-1, odczyt $\mathrm{z}$ dn. 19.12.2012. 
cechy, jest bowiem niewykształcony i niewyrafinowany politycznie ${ }^{51}$. Biorąc pod uwagę wyniki badań tej grupy wyborców, należy powiedzieć, że profil wyborcy populistycznego nie pokrywa się z profilem elektoratu Ruchu Palikota. Wyborców Ruchu Palikota najbardziej wyróżniają dwie cechy - młody wiek oraz nieuczestniczenie w praktykach religijnych, ale również zamieszkiwanie w dużych, aczkolwiek nie największych miastach, średnie i wyższe wykształcenie. Wysokość dochodów gospodarstwa domowego w niewielkim stopniu różnicowała poparcie dla tej partii, co może wskazywać, iż czynnik ekonomiczny nie miał znaczenia dla wyborcy Ruchu Palikota, dlatego też można uznać, że związek wyniku wyborczego tej partii z niezadowoleniem społecznym na skutek trudności ekonomicznych w państwie nie występuje. To kwestie światopoglądowe miały bardziej decydujące znaczenie. 20\% wyborców głosujących na RP nie bierze w ogóle udziału w praktykach religijnych, 17\% kilka razy w roku uczestniczy w praktykach religijnych, 10\% - 1-2 razy w i 5\% - raz w tygodniu. Osoby, które chodzą do kościoła kilka razy w tygodniu, w ogóle nie poparły RP. Nie zapominajmy również o wykształceniu wyborców RP, które wyraźnie jest wyższe niż typowej partii populistycznej ${ }^{52}$.

Koncepcja populizmu M. Marczewskiej-Rytko zakłada również istnienie społecznego kozła ofiarnego, jakim są mniejszości etniczne. Ruch Palikota nie kreuje takiego wroga ludu, a ochrona praw mniejszości jest jednym z głównych postulatów programowych. Postawa ksenofobiczna i inne krytykujące mniejszości są przez członków partii uznawane za naganne, oni sami są zaś reprezentantami różnych mniejszości ${ }^{53}$.

Kolejnym z kryteriów populizmu partii politycznej według R. Tokarczyka był charyzmatyczny autorytet. Czy Janusz Palikot jest przywódcą charyzmatycznym? Cech, które gwarantują nieomylność lidera i skuteczność działania ${ }^{54}$, obiektywnie nie posiada. Wprawdzie sam polityk określił się „mesjaszem lewicy” ${ }^{55}$, co może wskazywać na autokreację i mit personalny ${ }^{56}$, jednak nie porywa on obietnicami tłumów, ale od początku kierował swój przekaz i program do wąskiej, specyficznej

51 U. Jakubowska, Zainteresowanie polityka i postrzeganie własnej sytuacji życiowej a postawy populistyczne, [w:] Populizm a demokracja, op.cit., s. 24.

52 Wyborcy Ruchu Palikota, Komunikat z badań CBOS, BS/149/2011, Warszawa 2011.

53 Posłowie Robert Biedroń, Anna Grodzka.

54 A. Bembenista, Specyfika populistycznego przywództwa, [w:] Populizm na przełomie XX i XXI w., op.cit., s. 58 .

55 Palikot o sobie: ja, mesjasz lewicy, op.cit.

56 A. Bembenista, op.cit. 
grupy elektoratu, m.in. mniejszości seksualnych i środowisk antyklerykalnych, niezbyt powszechnych w polskim społeczeństwie. Obserwacja aktywności medialnej skłania do wskazania na dużą medialność tego polityka, którego kontrowersyjne wypowiedzi, zachowania i towarzyszące im rekwizyty stanowią atrakcyjny przekaz dla mediów. Przewodniczący Ruchu przyciąga uwagę wielu, podejmując działania skupiające uwagę mediów i opinii publicznej, nagłaśniając w niekonwencjonalny sposób konkretne problemy. Efekt ten potęgowany jest ponadto przez tabloidyzację mediów. Janusz Palikot wywołuje różne emocje, ale nie potęguje ich, mnożąc obietnice bez pokrycia. Nie kreuje się również na ojca narodu w czasach kryzysowych, gdyż czynnik nacjonalistyczny byłby sprzeczny z ideologią lewicowej równości. Wątpliwości w tym kontekście można wzbudzać nazwanie się przez Janusza Palikota mesjaszem lewicy, jednak warto dodać, że związane jest to bezpośrednio z konkretną ideologią, a więc $\mathrm{z}$ naturalnym zabiegiem kierowania przekazu do określonego segmentu elektoratu o preferencjach lewicowych.

Trzecim kryterium populizmu partii politycznej jest jej program polityczny. Ma go cechować kontekstowość, niespójność i eklektyzm. Jaki jest więc program Ruchu Palikota? Jest on lewicowy w sferze społeczno-obyczajowej ${ }^{57}$, w kwestiach gospodarczych jest natomiast liberalny ${ }^{58}$. $Z$ jednej strony można to uznać za brak spójności, z drugiej - za program partii typowo liberalnej. Poza tym nie można rozpatrywać programu RP w oderwaniu od pozostałych partii politycznych, których dokumenty programowe również krytykowane są za brak spójności. Stąd też należy zachować ostrożność w formułowaniu tezy o niespójnym, populistycznym programie Ruchu Palikota. Istotnie może on uchodzić za niespójny ideowo. Partia opowiada się za rozdziałem państwa i Kościoła, który to ma się odbyć poprzez: likwidację jego finansowania z budżetu, w tym likwidację funduszu świadczeń kościelnych, powrót lekcji religii do kościołów, uchylenie decyzji komisji majątkowej, zakaz uczestnictwa osób duchownych w uroczystościach świeckich. W kwestiach światopoglądowych partia domaga się legalizacji związków partnerskich, miękkich narkotyków, liberalizacji ustawy aborcyjnej, finansowania z budżetu zapłodnienia in vitro, zrównania pensji kobiet i mężczyzn, darmowego dostępu do środków antykoncepcyjnych

\footnotetext{
57 Program Nowoczesnego Państwa, www.ruchpalikota.pl, odczyt z dn. 19.12.2012.

58 Najbardziej charakterystyczny dla liberalizmu gospodarczego jest postulowany przez Ruch Palikota podatek liniowy. Reszta postulatów nie jest już tak konkretna.
} 
i Internetu ${ }^{59}$. Warto podkreślić, że większość $\mathrm{z}$ tych postulatów była głównymi hasłami podczas kampanii wyborczej do parlamentu w 2011 roku, a działacze środowisk je postulujących byli frontmenami partii, więc nie były one tylko elementem programu, ale jego trzonem. Zwłaszcza że pozostałe ugrupowania zrezygnowały z radykalnych postulatów z uwagi na ich niepopularność wśród większości społeczeństwa ${ }^{60}$. Świadome skupienie się na kwestiach mniejszościowych, niebędących wolą większości (ludu), może wskazywać, że kierownictwu partii nie zależało na manipulowaniu masami, ale na trafieniu do konkretnych grup wyborców, które nie są jednak liczne. Problemy poruszane w kampanii nie dotyczyły „ludu”, były uniwersalne, choć mogły spełniać warunek kontekstowości, przez co rozumiemy utworzenie partii na skutek „wydarzeń na Krakowskim Przedmieściu”. Z drugiej jednak strony wykorzystanie niszy wśród wyborców stanowi naturalny symptom demokratycznej rywalizacji wyborczej. Ponadto Ruch Palikota nie wykorzystał bieżących problemów w kampanii, mimo iż trwał kryzys finansowy, co jak wspomniano już wielokrotnie, jest jednym z czynników kształtujących zjawisko populizmu. Problematyka ta została poruszona w dokumencie programowym w części dotyczącej gospodarki ${ }^{61}$, jednak nie była eksponowana w takim stopniu jak część obyczajowa. W programie Ruchu znaleźć też można elementy populistyczne. Są to nawoływania do zmian elit rządzących przez nieskażonych władzą działaczy: „Nie jesteśmy kolejną układanką wśród tych samych elit - ile już ich było: AWS, PiS, PO, ZChN, PC, KPN, ROP, a teraz PJN - różne nazwy, a ci sami ludzie”. To prawda, że zdecydowana większość członków RP to de facto ludzie bez doświadczenia politycznego, ale już o liderze nie można tego powiedzieć. Faktem jest, że Janusz Palikot był skażony doświadczeniem politycznym, posłem z ramienia Platformy Obywatelskiej i członkiem komisji sejmowej „Przyjazne Państwo”. Wskazywanie na deficyt demokracji również może uchodzić za przejaw retoryki populistycznej, co znajdujemy w programie Ruchu Palikota.

Kolejnym z wyznaczników populizmu stosowanego przez partię polityczną jest demagogia. Rozumiana jako upraszczanie i nawoływanie do aprobaty nieprawdy, odwoływanie się do zdrowego rozsądku kosztem braku wnikliwej analizy może być cechą również Ruchu Palikota. Jego liderzy stosują uproszczenia, by wyjaśniać zawiłe problemy polityczne, tym bardziej że skupiają się na kwestiach

\footnotetext{
59 Program Nowoczesnego Państwa, op.cit.

60 Palikot jest prawdziwym zagrożeniem dla Platformy, op.cit.

61 Program Nowoczesnego Państwa, op.cit.
} 
światopoglądowych i społecznych, które są bardziej zrozumiałe dla wyborców niż debata nt. kwestii ekonomicznych. Przykładem jest jedna $z$ wypowiedzi lidera RP: „W Polsce za byle co można trafić do więzienia. Za obrazę uczuć religijnych, za obrazę prezydenta, za obrazę funkcjonariusza publicznego, za słowa - idzie się w naszym kraju do więzienia. Za wypicie piwa i prowadzenie roweru, za zapalenie jointa, za aborcję - idzie się do wiezienia62". Czy jednak Ruch Palikota nawołuje do akceptacji nieprawdy bez wnikliwej analizy problemów społecznych? Mimo całej specyfiki tego ugrupowania, czego przejawem są liczne prowokacje jej członków, partia zdaje się nie zachowywać wiarygodność i budować nowy wizerunek godny zaufania wyborców ${ }^{63}$. Ma też ograniczoną możliwość manipulacji opiniami swoich wyborców, których profil społeczno-demograficzny wskazuje na mniejszą podatność na demagogię - są dobrze wykształceni, choć młodzi (studenci). Zabieg manipulacji, jakim jest stosowanie obietnic bez pokrycia, jest też trudny do udowodnienia w sytuacji, gdy partia polityczna pozostaje w opozycji, wszelkie deficyty realizacji postulatów uzasadnia brakiem władzy. Andrzej Antoszewski wskazywał na fakt, iż konsekwencja w działaniu tej partii może stanowić o jej sukcesie ${ }^{64}$, jednak pewne niedociągnięcia w zakresie dotrzymywania słowa można zaobserwować już kilka miesięcy po wyborach parlamentarnych. Postulat neutralności światopoglądowej można uznać za działanie wymagające dłuższego wysiłku, a więc zapowiedź usunięcia krzyża z Sejmu - symbolizującego owy postulat - będzie najprawdopodobniej bardzo długo realizowany. Jednak jedna z obietnic Janusza Palikota została niespełniona. Odwołując się do części swojego elektoratu przez postulat depenalizacji posiadania marihuany, lider RP zapowiedział, że zostanie spalony „joint” w jednym z pokojów sejmowych przez któregoś z członków Stowarzyszenia Wolnych Konopii w celu sprawdzenia, czy uchwalona w 2010 roku ustawa funkcjonuje prawidłowo i rzeczywiście depenalizuje posiadanie niewielkich ilości narkotyków na własny użytek ${ }^{65}$. Ostatecznie do

62 Palikot wzywa wyborców o namysł i głosowanie na niego, http://wiadomosci.gazeta.pl/wiadomosci/1,114873,10431022,Palikot_wzywa_wyborcow_o_namysl_i_glosowanie_na_jego.html,odczyt $\mathrm{z}$ dn. 22.01.2012.

63 Palikot zapalił w Sejmie kadzidełko o zapachu marihuany, http://wiadomosci.gazeta.pl/wiadomosci/1,114877,11005387,Palikot_zapalil_w_Sejmie_kadzidelko_o_zapachu_marihuany.html, odczyt z dn. 22.01.2012.

64 Palikot jest prawdziwym zagrożeniem dla Platformy, rozmowa z Andrzejem Antoszewskim, http://wroclaw.gazeta.pl/wroclaw/1,35771,10473667,Palikot_jest_prawdziwym_zagrozeniem_dla_ Platformy.html, odczyt z dn. 19.12.2012.

65 Ruch Palikota zapowiada wypalenie jointa w sejmowym pokoju, http://wiadomosci.gazeta.pl/ wiadomosci/1,114877,10975721,Ruch_Palikota_zapowiada_wypalenie_jointa_w_sejmowym.html, 
tego nie doszło ${ }^{66}$. Była to jedna z prowokacji, jednak kontekst może wskazywać, że RP nie wywiązał się z obietnicy. Powszechnie wiadomo, że Ruch Palikota współpracuje ze Stowarzyszeniem Wolne Konopie, którego sympatycy moga stanowić jeden z segmentów elektoratu RP.

Miejsca i czasu jako wyznaczników populizmu w przypadku partii Ruch Palikota trudno się doszukiwać. Wynika to z nieobecności czynnika niezadowolenia ludu jako stymulującego i inicjującego powstanie partii populistycznej. Powiedziane zostało, że RP - mimo deklaracji w preambule dokumentu programowego - nie jest inicjatywą stworzoną oddolnie przez społeczne zaangażowanie jednostek, ale ugrupowaniem stworzonym przez jego obecnego przewodniczącego, byłego posła partii koalicyjnej. Jeśli negatywne nastroje społeczne nie stanowią głównej przyczyny powstania populistycznej partii politycznej, jej przewodniczący nie jest ich wyrazicielem i ucieleśnieniem (wybrańcem ludu), a proces powstawania partii jest rozciągnięty w czasie, to trudno wskazać na obiektywne okoliczności jako cechę populistyczną partii Ruch Palikota. Nie odnajdujemy zewnętrznego stymulatora w społeczeństwie, które doprowadziłoby do powstania populistycznej partii.

Brak hegemonii ludu jest kolejnym $\mathrm{z}$ argumentów zaprzeczających tezie o populizmie Ruchu Palikota. Trudno dopatrywać się odwołań tej partii do pojęć: narodu, ogółu ludności utrzymującej się z własnej pracy, ludności wiejskiej. Naród bowiem kojarzy się wykluczeniem jednostek, które nie są jego reprezentantami, co z kolei jest sprzeczne z lewicowymi ideałami poszanowania praw mniejszości, głoszonymi przez Ruch Palikota, i znajduje swój wyraz w programie partii: „Mamy dość tego, że ktoś za nas decyduje [...] kto to jest Polak" ${ }^{67}$. Partia nie odwołuje się też do ludzi pracy, choć opowiada się za silną pozycją polityki społecznej, jednak tradycyjny elektorat robotniczy nie jest głównym adresatem przekazu, jak wynika ze wspomnianych wyżej badań. Ich wyniki wskazują bowiem na elektorat młody, lepiej wykształcony, zatrudniony w usługach, administracji biurowej i publicznej lub pracujący na własny rachunek. Robotnicy wykwalifikowani i niewykwalifikowani stanowią 10\% elektoratu. Lewicowość RP przejawia się w akcentowaniu liberalnych postulatów aksjologicznych, w mniejszym stopniu jest to przekaz do robotników. Do zastanowienia może skłaniać, czy na populizm Ruchu Palikota

odczyt z dn. 22.01.2012.

66 Palikot nie zapalił, ale i tak może mieć problemy, http://wiadomosci.gazeta.pl/wiadomosci $/ 1,114884,11004200$,Palikot_nie_zapalil_ale_i_tak_moze_miec_problemy_html, odczyt z dn. 22.01.2012.

67 Program Nowoczesnego Państwa, op.cit. 
wskazuje fakt, że jednym z segmentów jego elektoratu jest ludność wiejska (10\% ). Co prawda jest to wielkość równa z poparciem robotników dla tej partii ${ }^{68}$, czyli nieduża, ale warto się odnieść do badań populizmu w Polsce, które wskazują, że jest on silniejszy w mniejszych miejscowościach ${ }^{69}$. Należy zaznaczyć, że największą grupą elektoratu Ruchu Palikota byli mieszkańcy właśnie wsi (11\%) i miejscowości o liczbie mieszkańców 101-500 tys. ${ }^{70}$, czyli tych, gdzie zaobserwowano wysoki poziom populizmu. Wskazywałoby to na niekorzyść założonej na wstępie pracy hipotezy, jednak nie jest to elektorat docelowy, będący konsekwencją podziału socjopolitycznego miasto-wieś.

Hegemonia ludu oznacza też zgodność z oczekiwaniami większości, wolą społeczeństwa, powoływanie się na instynkt mas, jednak trudno dostrzec również tę cechę populistycznego obrazowania przez Ruch Palikota. Partia, skupiając się na marginalnych dla większości społeczeństwa kwestiach, takich jak poszerzenie praw mniejszości seksualnych czy postulowanie kontrowersyjnych haseł związanych z neutralnością światopoglądową państwa, nie jest nastawiona na pozyskanie głosów większości społeczeństwa, dodać należy, że wyniki wyborów parlamentarnych w 2011 roku wskazują na prawicowe preferencje wyborców. Za racjonalny wniosek można uznać, że partia, która celowo, świadomie decyduje się na reprezentowanie elektoratu mniejszościowego, niszowego wyklucza populizm rozumiany jako vox populi, vox dei ${ }^{71}$.

Ostatnia cecha konstytutywna populizmu, jaką proponował R. Tokarczyk, to wielość inspiracji, a więc kombinacja różnych ideologii, często postulowanie trzeciej drogi i możliwości pogodzenia myśli lewicowej z prawicową. Można powiedzieć, że w tym aspekcie ruch Palikota jest modelowym przedstawicielem populizmu. Odnajdujemy to zarówno w programie, jak i w wypowiedziach polityków tej partii. Bez wątpienia dostrzegamy postulaty lewicowe w sferze światopoglądowej i związany z tradycją prawicy nacisk na rozwój przedsiębiorczości, postulowanie podatku liniowego czy nawet sprzeciw wobec biurokracji ${ }^{72}$, charakterystyczny dla partii tzw. nowej prawicy, nowego populizmu. Z jednej strony jest to przykład działań partii liberalnej, z drugiej jednak strony RP wyraź-

68 Wyborcy Ruchu Palikota, op.cit.

69 Populizm Polaków u progu $i$ w środku kampanii wyborczej, Komunikat z badań CBOS, BS/121/2011, Warszawa 2011.

70 Wyborcy Ruchu Palikota, op.cit.

${ }^{71}$ K. Wojtas, Populizm, http://www.omp.org.pl/stareomp/index5efd.html?module=subjects\&fun$\mathrm{c}=$ viewpage\&pageid $=339$, op .cit.

72 Program Nowoczesnego Państwa, op.cit. 
nie podkreśla lewicowość. Oprócz postulatów neutralności światopoglądowej, bezsprzecznie wiązanych $\mathrm{z}$ tradycją lewicy, partia akcentuje kwestie socjalne, ale też jest nastawiona na współpracę ze środowiskami przedsiębiorców, którzy są de facto jej członkami. Świadomość pewnej sprzeczności pomiędzy tymi postulatami występuje wśród działaczy Ruchu Palikota, którzy tłumaczą ją celowym zabiegiem, koniecznością sfinansowania polityki socjalnej państwa dochodami z rozwoju przedsiębiorczości, a także próbą pogodzenia interesów, unikania antagonizowania społeczeństwa ${ }^{73}$ i zapewne ma zaprzeczać skojarzeniom z populizmem. Racjonalizacja rozwiązań programowych - łączenia postulatów socjalnych $\mathrm{z}$ rozwojem prywatnej przedsiębiorczości stanowi prawdopodobnie najsilniejszy argument na niekorzyść partii Ruch Palikota, wykorzystywany przez ugrupowania konkurencyjne, deklarujące określoną opcję polityczną przeciwko $\mathrm{RP}$ oraz przechwytywane przez media formułujące w następstwie tezę o populizmie. Próba racjonalnego pogodzenia postulatów prawicowych z lewicowymi wpływa na zainteresowanie partii deklarujących te poglądy na wyłączność. Ruch Palikota stanowi zagrożenie dla partii obu biegunów rywalizacji politycznej, a więc źródło opinii o populizmie tego ugrupowania jest podwójne, potęgowane przez media masowe. Mimo tego, że siła argumentu wydaje się duża, nie powinno się zapominać o tym, iż wynika ona głównie z odpowiedniej oprawy medialnej, a więc z braku wnikliwej i rzetelnej oceny zjawiska populizmu. Przejawem tego jest choćby brak analizy populizmu Ruchu Palikota w odniesieniu do pozostałych czynników.

\section{ZAKOŃCZENIE}

Należy potwierdzić postawioną na wstępie hipotezę, która mówi, że partia Ruch Palikota nie jest partią populistyczną, ponieważ nie spełnia konstytutywnych założeń populizmu. Powyższe rozważania temu dowiodły i w ramach podsumowania warto je przypomnieć. Ruch Palikota nie przejawia znamion: niezadowolenia ludu - powstanie RP jest inicjatywą polityka wywodzącego się z partii rządzącej w okresie powstawania RP; autorytetu charyzmatycznego - przewodniczący Janusz Palikot nie posiada charyzmy i nie wykorzystuje jej do porywania tłumów, jest za to bardzo medialną postacią; metody populistyczne - metody stosowane przez polityków Ruchu Palikota nie są manipulacją, charakteryzuje je kontro-

${ }^{73}$ Eksperyment intelektualno-programowy, op.cit. 
wersja i nietypowość; miejsce i czas - do obiektywnych przyczyn powstania RP zalicza się inicjatywę polityka, a nie kryzys i masowe niezadowolenie; hegemonii ludu - Ruch Palikota nie prezentuje haseł dostosowanych do oczekiwań większości społeczeństwa, ale kładzie nacisk na postulaty kontrowersyjne, kierując do wąskiej grupy społeczeństwa, jakim są m.in. mniejszości seksualne czy antyklerykałowie.Znamiona populizmu w Ruchu Palikota to myśl populistyczna i wielość inspiracji, a więc niespójny i eklektyczny program, będący emanacją utopijnej wizji pogodzenia postulatów z przeciwnych biegunów rywalizacji politycznej, osi lewica-prawica. Istnieje przewaga liczbowa argumentów zaprzeczających tezie o populizmie Ruchu Palikota nad potwierdzającymi ją. Warto też dodać, że zarówno myśl populistyczna, jak i element synkretyzmu ideologicznego są elementami pozostałych partii politycznych obecnych w kadencji parlamentu rozpoczętej w 2011 roku. Tak więc można powiedzieć, że poziom populizmu Ruchu Palikota nie jest wyższy niż u pozostałych partii politycznych. Nie powinien więc budzić większych kontrowersji wśród polityków i w mediach. Jest odwrotnie, gdyż odpowiednia polityka komunikacyjna ugrupowania - przy postępującej mediatyzacji i tabloidyzacji polityki - sprawia, że jest ono w szczególnym stopniu poddawane ocenie w środowisku politycznym i wśród opinii publicznej.

Warto w tym kontekście zastanowić się nad znaczeniem programu politycznego we współczesnych badaniach nad profilem ideowym partii politycznych. Obecnie dostrzega się kryzys tego czynnika, program może być bardzo lewicowy lub bardzo prawicowy, natomiast praktyka funkcjonowania partii politycznej w warunkach rywalizacji politycznej bądź w mediach może powiedzieć więcej, można nawet dostrzec rozdźwięk pomiędzy deklaracjami programowymi a działalnością w organach ustawodawczych. Dokumenty programowe stanowią ważny składnik kampanii wyborczej w mediach i bezpośredniej, natomiast już mniejszą rolę odgrywają po wyborach. Może się więc okazać, że szczegółowa i rzetelna analiza programu jest zbyteczna, albowiem został on napisany w trosce nie o zachowanie czy podkreślenie profilu ideologicznego, ale o poparcie, a więc istnieje duże prawdopodobieństwo, że będzie on skonstruowany na potrzeby kampanii, co w efekcie czyni go populistycznym. Postulaty „pod publiczkę” stanowią naturalny symptom, tak więc populizm w tym obszarze zdaje się coraz częstszym zjawiskiem i dotyczy coraz to większej liczby partii politycznych. Można powiedzieć, że jest tak stary jak same partie polityczne. 